\title{
Mycosphere Essays 3. Myxomycete spore and amoeboflagellate biology: a review
}

\author{
Jim Clark ${ }^{1}$ and Edward F. Haskins ${ }^{2}$ \\ ${ }^{1}$ Department of Biology, University of Kentucky, Lexington, Kentucky 40506 \\ ${ }^{2}$ Department of Biology, University of Washington, Seattle, Washington 98195
}

Clark J, Haskins EF. 2016 - Mycosphere Essays 3. Myxomycete spore and amoeboflagellate biology: a review. Mycosphere 7(2), 86-101, Doi 10.5943/mycosphere/7/2/1

\begin{abstract}
The spore and amoeboflagellate stages of the heterothallic myxomycete life cycle are generally a uninucleate haploid alternative to the multinucleate diploid plasmodial stage. The spore is produced in a sporangium which develops from the plasmodium, and is a dispersal and resistant stage which has ornamentations that can be used in taxonomy. These small spores have thick pigmented walls and are generally wind dispersed and require water and other biological and physical conditions in order to germinate; this dispersal can occur over long distances and the germination conditions apparently vary between and within a species. The amoeboflagellate stage has three alternative phases: myxamoeba, swarm cell and cyst. The myxamoeba is a typical pleomorphic amoeboid cell that is the major phase, since it is the vegetative phase that ingests bacteria and yeasts, and divides mitotically to form a clonal population of cells. The myxamoeba of heterothallic strains can also, after reaching a certain cell density, become sexually competent and fuse to produce the plasmodial stage. The swarm cell phase develops from the myxamoebal stage when free water is present; it also feeds on bacteria but does not divide unless it reconverts to the myxamoebal phase. The cyst phase develops from the myxamoebal stage, when growth conditions become adverse, by the condensing of the cell and the formation of a resistant wall.
\end{abstract}

Key words - cyst - myxamoebae - spore dispersal - swarm cell

\section{Introduction}

The life cycle of the heterothallic myxomycetes as it is typically presented consists of alternating trophic generations; the macroscopic multinucleate diploid plasmodial stage and the microscopic uninucleate haploid amoeboflagellate stage. The diploid plasmodial stage after a period of growth converts into a sporophore which produces many small uninucleate haploid spores by meiosis of the diploid spore nuclei and the degeneration of three of the four resulting haploid nuclei (Aldrich 1967). These spores, which are generally wind dispersed, then germinate to produce the microscopic haploid amoeboflagellate stage which can exist in three different forms; the amoeboid myxamoeba, the flagellate swarm cell, or the resistant cyst. Amoeboflagellates, after a period of growth, convert into gametes that fuse to form a zygote (see review by Clark \& Haskins 2013), which then develops into the plasmodium by mitotic nuclear divisions without cell division. However, in many different isolates of myxomycete species, the nuclear cycle in this basic life cycle does not occur (see Clark \& Haskins 2013). In these isolates nuclear division during spore 
production is automictic, so that the resulting spores and amoeboflagellates remain diploid. However, the morphology and biology of the amoeboflagellate, except for sexual fusion, is retained in these isolates.

\section{Spores}

With the classification of the exosporous Ceratiomyxa species, which produce single stalked spores on the surface of the sporophore, as Protostelids all of the myxomycetes are now endosporous, with the spores produced within a sporophore by successive cleavages of the protoplasm and the formation of spore walls around each uninucleate unit (Aldrich 1967). Spores are cleaved out of the sporothecal protoplasm by means of vesicle fusion which produces uninucleate segments of protoplasm around which spore wall materials are deposited (Mims 1972). The small spherical spores have thick walls and thus they can serve as resistant structures as well as dispersal units which are spread by wind and other incidental methods. The different species also have distinctive color and surface ornamentation which provide useful taxonomic characters.

\section{Endosporic Meiosis}

There was a disagreement among early workers concerning where meiosis occurred during spore formation, or even if it occurred in the sporangium (see review by Clark \& Haskins 2010). In the heterothallic isolates (amoeboflagellates of different mating types must cross to produce a plasmodium), it has been determined that during spore formation a single diploid nucleus is enclosed in the developing spore, which then undergoes meiosis with three of the resulting nuclei degenerating to leave the spore uninucleate and haploid (Aldrich 1967, Laane \& Haugli 1976). However, in the non-heterothallic isolates (a single amoeboflagellate can develop into a plasmodium), it was assumed that the non-heterothallic isolates were either homothallic (meiosis occurred but that any two amoeboflagellates could fuse to produce the plasmodium) or that meiosis did not occur and an amoeboflagellate simply developed into the plasmodium. Reports that there was no ploidal change between the amoeboflagellate and plasmodial stages (Haskins \& Therrien 1978, Collins et al. 1983) ruled out homothallism, and the finding of synaptonemal complexes (indicators of chromosome pairing in meiosis) in the developing spores (Haskins \& Therrien 1978) contradicted direct development. This puzzle was resolved when it was found that the second division of meiosis did not occur in the spores of isolates where synaptonemal complexes occurred (Therrien \& Haskins 1981); apparently these isolates undergo an automictic division. In automixis the first division of meiosis (Meiosis I) occurs, but the second division (meiosis II) does not; this results in the reformation of the diploid nucleus which retains both mating types which allow the amoeboflagellate to develop into a plasmodium.

\section{Spore Morphology}

Myxomycete spores are small spherical to rarely ovoid dispersal units with pigmented thick walls that are generally covered with warts, spines, ridges or other ornamentations. Spores from different species of myxomycetes vary in size from four to twenty five $\mu \mathrm{m}$ in diameter, although the majority of species fall within a seven to twelve $\mu \mathrm{m}$ range (Schnittler \& Tesmer 2008). While spore size, which is a useful taxonomic character, is reasonably stable for a particular species; size variations within a species are generally larger than many descriptions indicate, and may vary with the conditions of sporulation (Solis 1962).

\section{Pigmentation}

Myxomycete spores can be divided into two basic groups based upon pigmentation (Martin \& Alexopoulos 1969); the dark spored (brown, purple and black) and the light spored (colorless, pallid yellow brown, yellow and red) species. This division of the species by spore color is a near perfect correlation to the two major clades determined by DNA phylogeny (Fiore-Donno et al. 2009). Thus spore color, by both transmitted light (with a microscope) and in mass (the appearance of the spore mass of a specimen), are basic taxonomic characters. The chemical nature of these 
spore pigments is not well known. However, melanin has been reported in the spore walls of several dark spored Stemonitales and Physarales species (Loganathan et al. 1989), and is probably the source of the brown and black colors in most myxomycete species. In the light spored species, the naphthoquinone extracted from sporangia of a Cribraria species (Iwata et al. 2003) and the indole derivatives extracted from a number of Arcyria species (Rebhahn et al. 1999), may also be present in the spore walls. In any case, it appears that the presence or absence of melanin in the spore wall is the major factor distinguishing the dark and light spored groups from each other; although Aldrich \& Blackwell (1976) suggest that small amounts of melanin may also occur in the spore walls of light spored species.

\section{Wall structure}

While earlier studies (Boic 1925, Schuster 1964a), using chemical staining techniques, suggested that myxomycete spore walls contained cellulose; McCormick et al. (1970), using a direct chemical analysis, found that the major wall component, in Physarum polycephalum spores, was a galactosamine polymer $(81 \%)$ with smaller amounts of melanin, amino acids and phosphate. Electron microscopy of spore walls, in a number of species, (Schuster 1964b, Scheetz \& Alexopoulos 1971, 1976, Mims 1972, Randall \& Lynch 1974, Bechtel 1977) shows a two layer structure, with a thin fibrillar outer electron dense layer, which presumably contains the melanin and other pigments, and an inner thick electron lucent layer. However, the spores of several Echinosteliales species display some differences from this norm (Haskins \& McGuinness 1986); with Echinostelium minutum and E. coelocephalum having the normal thicker inner spore layer, E. arboretum and $E$. corynophorum having equal sized layers, and $E$. bisporum having a thicker outer layer; and all species having fibrillar channeled sculptured elements in the outer layer that are not present in other species. Also Semimorula liquescens, another member of the Echinosteliales, has only a single loose electron dense fibrillar layer without any channel elements, which makes it more similar to the two protostelid species examined, than to the rest of the Echinosteliales (Haskins \& McGuinness 1986). A few species have clustered spores; however, they are generally rare and often have a non-clustered spore counterpart that is identical or very similar to them (Schnittler \& Mitchell 2000). In these clustered spore species, the mature spores are held together by a variety of mechanisms (Demaree \& Kowalski 1975); in some species the spore walls are fused together along their entire appressed surfaces, at numerous specific points of contact, or at the tips of the ornamentations, while other species appear to be cemented together by a separate substance.

\section{Wall ornamentation}

Spore wall ornamentation is an important species level taxonomic character (Martin \& Alexopoulos 1969), which has increased in importance with the development of electron microscopical studies (Schoknecht \& Small 1972, Rammeloo 1974, 1975, Scheetz \& Alexopoulos 1971, 1976, Haskins \& McGuinness 1986, Neubert \& Baumann 1987, Neubert et al. 1987, 1989, Lizárraga et al. 1999) that have provided details irresolvable with the light microscope; including micro-ornamentations which can be found on what were considered to be smooth spores (Haskins $\&$ McGuinness 1986). These ornamentations are projections of the outer spore wall layer, except for some ridges which are formed by folds of the entire spore wall (Scheetz \& Alexopoulos 1971, 1976). With this increased resolution a new terminology has been proposed by Rammeloo (1974). The ornamentations are classified as pila (swollen heads on a cylindrical base), bacula (cylindrical processes without a head), verrucae (irregular short processes), spines (long pointed processes), coni (short blunt pointed processes), muri (ridges having smooth surfaces), and cristae (ridges consisting of jointed pili, bacula or other processes), with individual spores having one or more types of processes. With the light microscope these ornamentations are usually classified as spines (spines and some coni), warts (pili, bacula and some coni) and ridges (muri, cristae). These spore characteristics are considered to be quite constant, especially at the species level, however, they can and do vary in different isolates of the same species (Martin \& Alexopoulos 1969, Gaither \& Collins 1984, ElHage et al. 2000, Fiore-Donno et al. 2011). In fact, as in the case for most 
characteristics, spore ornamentation, size and color may be all alike or vary in one collection to another of the same species. Therefore, a number of isolates must be studied to determine the morphological range of spore characteristics for a particular species, which in certain cases may be quite wide.

\section{Cytoplasm}

While the cytoplasm of the spore is in the compact state of an inactive cell, it has all of the normal eukaryotic organelles such as nuclei and mitochondria (Schuster 1964). Each spore typically has a single nucleus, although mitotic nuclear division may occur prior to spore germination (Koevenig 1964), and the spores also have basal bodies that are necessary for flagellar formation (Aldrich 1967).

\section{Spore Dispersal}

The spore is the major long-distance dispersal unit of the myxomycetes, and appears to be very effectively dispersed over ranges extending from meters to possibly worldwide. It is small, highly resistant and adapted to both wind and incidental dispersal by animals and environmental factors.

\section{Wind dispersal}

Wind is undoubtedly the mechanism of long distance dispersal of myxomycete spores, and the distance moved is probably only limited by the survival of the spore's exposure to UV light. However, the thick pigmented spore wall probably provides considerable protection against UV light which is normally deadly to small unprotected organisms. Considerable levels of airborne spores of a number of different species have been detected using molecular techniques (Kamono et al. 2009) and agar exposure methods (Brown et al. 1964). Also experiments studying the removal of spores from the sporophore by air currents (Brodie \& Gregory 1953), sedimentation velocity (Tesmer et al. 2007), and the adequacy of the spore-rain (Schnittler et al. 2006, Schnittler \& Tesmer 2008), have shown that wind dispersal is a very efficient mechanism for colonizing viable habitats within distances of 50 meters. Also, DNA studies of geographical widespread collections of Didymium squamulosum (Winsett \& Stephenson 2008) and Didymium difforme (Winsett \& Stephenson 2011) sporangia indicate that successful long distance dispersal occurs in these species. The major difficulty for wind dispersal of spores is probably the initial problem of dry spores reaching turbulent air, which in the case of most myxomycetes is partially solved by the plasmodium moving to an exposed surface prior to sporulation and the production of a stalked sporophore which helps raise the sporotheca and its spores into the drying air and above the laminar air flow that surrounds any surface.

\section{Incidental dispersal}

Numerous small animals, such as beetles, slug, mites and earthworms, feed on or in the habitat of myxomycete plasmodia and sporophores (Blackwell et al. 1982, Murray et al. 1985, Newton \& Stephenson 1990, Stephenson \& Stempen 1994, Keller \& Snell 2002), and can transport the spores either in their guts or stuck to their surfaces. It has been shown that the spores which pass through the gut of mites and earthworms retain their viability (Murray et al. 1985, Keller \& Snell 2002). Thus, short range dispersal can occur through animal transport and incidental water movement by means of raindrop splashing (Dixon 1963) or running water, which may be facilitated by hydrophobic effects caused by spore ornamentation (Hoppe \& Schwippert 2014).

\section{Spore Germination}

The germinating spore releases one to several amoeboflagellates, which are either flagellate (swarm cells) or non-flagellate (myxamoebae). These amoeboflagellates are released from the spore via means of pores, splits or dissolution of the spore wall (deBary 1864, Jahn 1905, Haskins et al. 1983). 


\section{Physical conditions}

The physical conditions, for myxomycete spore germination vary from species to species, with water being the major constant requirement. While many species will germinate in distilled water at room temperature in less than an hour (Gilbert 1928a) other species (and sometimes isolates of the same species) require more elaborate conditions (see Haskins \& Wrigley de Basanta 2008 for an overview of culturing methods). Various experiments have been conducted concerning the following physical conditions for germination: nutrients, $\mathrm{pH}$, temperature, wetting and drying, and light. Weak nutrients (Cooke \& Holt 1928), often in the form of substrate extracts (Alexopoulos 1960, Haskins \& Wrigley de Basanta 2008), have been found to enhance, or be required for, germination of some species. The effects of $\mathrm{pH}$ on spore germination for a number of species (Smart 1937, Abe 1941) is fairly uniform; with most species germinating reasonably well (50\% of spores) between a $\mathrm{pH}$ of 4 to 8 with a maximum germination rate near $\mathrm{pH} 7$. However, some species, such as Comatricha laxa, have a more constricted $\mathrm{pH}$ range (5-7) for germination. Smart (1937) also examined the effects of temperature on spore germination in a number of species of myxomycetes; he found that while germination, in some species, occurred at temperatures as low as $2^{\circ} \mathrm{C}$ or as high as $36^{\circ} \mathrm{C}$, the optimal temperature for germination of all of the species tested was in the range of $22^{\circ}$ to $30^{\circ} \mathrm{C}$. Recent research on the nivicolous (snow bank) myxomycetes (Ronikier et al. 2010, Shchepin et al. 2014) seems to indicate that this group may germinate at a range of temperatures $\left(2-23^{\circ} \mathrm{C}\right)$, however, this is a group where temperature experiments and culture work are still needed. While spore germination requires the uptake of water, the spore walls are hydrophobic; and therefore the wetting of the spore can affect sporulation. Thus the use of dilute bile salts as a wetting agent (Elliott 1949), or alternate wetting and drying cycles (Lister 1901, Jahn 1905, Gilbert 1929, Smart 1937, Elliott 1949) has been found to increase germination rates in a number of species. The report (Hoppe \& Schwippert 2014) that highly ornamented spores are more hydrophobic than smooth spores may explain some of these differences in germination. Although Cooke \& Holt (1928) reported that Stemonitis splendens spores germinated better in darkness, Smart (1937), using the same species, found no light effect on germination.

\section{Biological conditions}

Both external and internal biological factors apparently influence spore germination. The external factors are the other microorganisms present in the environment, which could secrete substances that are inhibitory or enhancing to germination. Although, there are several reports concerning the germination of spores, of certain species, occurring only in the presence of a microorganism derived from the natural substrate (Olive 1960), this is an area where little is known and where useful research could be conducted. Some internal biological factors which could affect spore germination are maturation, longevity, release of an autocatalytic factor or enzyme activation. Gilbert (1929) has reported that the spores of some species require a post-sporulation maturation period before they can germinate, with Lycogala epidendrum needing at least a month of maturation and Reticularia rozeanum improving in germination percentage for up to two years of maturation. However, in the experience of the authors, who have cultivated many different species during their careers, the spores of most species of myxomycetes will germinate immediately after sporulation or they will not germinate at all.

The viability of spores over time has been studied by a number of individuals (deBary 1864, Smith 1929, Gilbert 1929, Elliott 1949, Erbisch 1964), and reports of spores germinating from herbarium collections up to 75 years of age have been published. However, since these cultures were not grown from spore to spore, the real possibility of cross contamination, especially in a herbarium situation, cannot be discounted. In general, most researchers (including the authors) find that spore viability declines rapidly after one year and that spores older than four year seldom germinate (Winsett 2011). Smart (1937) reported that large spore masses seemed to germinate more rapidly and achieve a higher germination percentage than less dense concentrations, and that spores germinated faster on a medium on which other spores had previously germinated. He thus hypothesized that spores released an autocatalytic substance which enhanced germination. 
Dahlberg \& Franke's (1997) study of spore germination in Fuligo septica also supports the existence of a soluble autocatalytic factor. However, mating type studies on many species of myxomycetes using single spore isolates (see review by Clark \& Haskins 2010), indicate that the spores of many species have no difficulty in germination by themselves; and other studies, on a number of species (Kerr 1982, Haskins \& Hinchee 1992) find no evidence of an autocatalytic factor. Since spore germination involves the escape of the amoeboflagellate via splits, pores or dissolution of the wall (deBary 1864, Jahn 1905), it is apparent that enzymatic activity may be involved; however, except for the possible activation of the enzymes by the entry of water into the spore, little is known of this process, except that aeration enhances spore germination (Braun 1971) and that osmosis may be involved (Haskins \& Hinchee 1992). In general, we know very little about the internal control of spore germination, and have no way of explaining why the spores of some isolates and individual sporangia of the same species can be germinate without any difficulty, while others germinate either very poorly or not at all in the same situation (Clark 2003, Winsett 2011).

\section{Multiple amoeboflagellates}

While deBary (1864) was the first to report the emergence of more than one amoeboflagellate from a single spore, Smith (1929) was the first to study and compile the information on multiple amoeboflagellate germination. He determined that in the 33 species of myxomycetes studied by him and others, that they all could produce one to two amoeboflagellates, and that some species could produce four or rarely eight separate amoeboflagellates. The reason for multiple amoeboflagellate emergences from spores is not completely settled, since it could be due to the incorporation of more than one nucleus in the developing spore, by meiosis of a single diploid nucleus within the spore without degeneration of any of the resulting haploid nuclei, or by mitosis of a haploid or diploid nucleus within a spore. However, Koevenig (1961) has provided direct film evidence for mitosis in a single nucleated spore of Fuligo septica and the emergence of two amoeboflagellates from that spore, and a recent review (Clark \& Haskins 2013) concludes that the preponderance of evidence indicates that most or all multiple emergences are due to the mitotic divisions of an original single nucleus.

\section{Release method}

The amoeboflagellates are released from the spore by either a split in the cell wall, a pore in the cell wall, or by the dissolution of the entire cell wall. The majority of species germinate using the split or pore process which was first reported by deBary (1864) and Jahn (1905); and later confirmed by Gilbert (1928a). In the split method, the wall apparently weakens on a line and is ruptured in a wedge shaped split that widens and allows the amoeboflagellate to emerge. In the pore method, a portion of the wall apparently weakens and a small irregular hole opens up in the wall through which the amoeboflagellate slowly exits. These two processes are apparently very similar, since Kovenig (1964) could convert the split germinating spores of Physarum gyrosum to pore germinating by adding cellulase to the germination water; and Smart (1937) could convert the pore germinating spores of Reticularia splendens to split germinating by manipulating the temperature during the process. Electron microscopic studies of spore germination indicate that the exit pore is preformed in Stemonitis virginiensis (Mims \& Rogers 1973), but the slit of Arcyria cinerea (Mims 1971) and pore of Echinostelium minutum (Haskins \& Hinchee 1992) are not. The third germination method involving the softening and gradual disappearance of the cell wall is less common and has only been reported to occur in Ceratiomyxa fruticulosa (McManus 1958); while the thin cell wall of Semimorula liquescens undergoes dissolution and re-absorption during germination (Haskins et al. 1983). Apparently, in most cases, the uptake of water by the spores activates enzymes which soften a specific region of the wall which then ruptures by osmotic pressure and amoeboflagellate movement.

\section{Amoeboflagellates}

The amoeboflagellate life cycle stage of the myxomycetes has three alternative states; the 
amoeboid myxamoebae, the flagellate swarm cells, and the resistant cyst stages. The myxamoeba is the central state in this life cycle stage since the other two states are not generally necessary for completion of the life cycle. The myxamoebae are capable of feeding, dividing mitotically and producing the plasmodial stage of the life cycle; while the swarm cells which are capable of feeding and producing the plasmodial stage do not undergo mitotic division, and the cysts are strictly resistant structures.

\section{Amoeboflagellate Morphology}

All three of the amoeboflagellate states are colorless, microscopic and usually haploid (in heterothallic strains) uninucleate cells with morphologies that are adapted to their life cycle functions; the generalist myxamoebae, the swimming swarm cell and the resistant cyst.

\section{Myxamoebae}

The microscopic (approximately $10 \mu \mathrm{m}$ in diameter) uninucleate myxamoebae have the pleomorphic shape common to all soil amoebae which lack a cell wall; however, they do have a very thin $\left(200 \mathrm{~A}^{\circ}\right)$ flexible coat outside of their cell membrane (Dykstra \& Aldrich 1978). The interior of the cell contains small, but normal eukaryotic organelles: a nucleus with a double membrane and a nucleolus, numerous tubular cristae mitochondria similar to those found in many other protozoan amoebae, an endoplasmic reticulum, a Golgi apparatus, a contractile vacuole, two centrioles, and food vacuoles (Schuster 1965, Aldrich 1968).

\section{Swarm cells}

Swarm cells have an elongate shape with a cone-shaped anterior and a wider somewhat amoeboid posterior region. The flagella, centrioles and nucleus are located at the anterior region which is shaped and maintained by a conical arrangement of microtubules (Cadman 1931, Schuster 1965, Aldrich 1968, Wright et al. 1979). The posterior region contains mitochondria, a contractile vacuole and other organelles; it also produces pseudopodia which adhere to bacteria and other food particles which are ingested into food vacuoles. Each swarm cell usually has two heterokont whiplash flagella, one of which is normally short and carried pressed to the cell membrane where it is difficult to detect (von Stosch 1935, Elliott 1949). While, there are numerous reports of one to eight flagella per cell, the most common number within most specific cultures is two per cell (Elliott 1949, Haskins 1978). One explanation for this variation is the presence of pseudoflagella (membrane extensions lacking the nine plus two array of microtubules found in true flagella) which occur in some cultures (Koevenig 1961) that can be mistaken for flagella. However, some variations appear to be normal variations or developmental abnormalities; as in Echinostelium minutum where the flagella are always isokont (equal in size), and where some swarm cells, from the same isolate, have varying numbers (1-8) of flagella (Haskins 1978) possibly due to polyploidy, which is supported by high voltage electron microscopic studies of chromosomes (Haskins 1976).

\section{Transition}

The myxamoebae and swarm cells are generally believed to be capable of multiple reversible transformations between the two forms, although Ross (1957) believed that some species lose the ability to reversibly transform after a period of growth and thereafter remained either myxamoebae or swarm cells. Myxamoebae transform into swarm cells by the formation of centrospheres on the nuclear membrane, consisting of the Golgi apparatus and centrioles, which then move to the cell membrane and elongates the nucleus and cell with the formation of a microtubular cone structure (Schuster 1965, Aldrich 1968, Wright et al. 1979). This forms the anterior end of the swarm cell and the remaining cytoplasm and organelles move to the other end of the cell to produce the posterior end. The flagellar sheath is then produced by the Golgi vesicles and the inner flagellar microtubules are formed from the basal bodies (Aldrich 1968). Swarm cells transform into myxamoebae by absorbing the flagella, either by whipping it against and fusing with 
the cell membrane or pulling it in by movement of the nucleus, as the cone structure disperses (Koevenig 1964).

Cyst

The resistant cyst is derived from the myxamoeba by the rounding up of the amoeboid cell, condensation of the cytoplasm, disappearance of food vacuoles and contractile vacuole, and the formation of a cyst wall (Koevenig 1964). The cyst wall consists of one to several randomly arranged microfibril layers (depending upon the species) which may display small spine-like ornamentations (Schuster 1965, Aldrich \& Blackwell 1976, Haskins et al. 1985). In Physarum flavicomum this wall consists of 32.1\% D-galactosamine, 10.4\% neutral sugars, $21.8 \%$ lipids, 21.2 $\%$ proteins, $5-8 \%$ phosphate, and $8.7 \%$ undefined materials (Henney \& Chu 1977b); however, in Physarum polycephalum (McCormick et al. 1970) it consists of glactosamine (98\%), and protein (2\%) without any lipids. In most species examined to date, excystment occurs by means of a pore dissolved in the wall through which the amoeboflagellate exits (Howard 1931, Aldrich \& Blackwell 1976), however, in Echinostelium minutum the cyst wall completely dissolves (Haskins et al. 1985).

\section{Amoeboflagellate Physiology}

\section{Transitions}

The myxamoebal to swarm cell transition occurs within a few minutes with the addition of water to the culture, and the subsequent removal of the water cause the cell to revert to the amoeboid state (Kerr 1960, Aldrich 1968), although large populations of bacteria may inhibit the transition (Kerr 1965a). The encystment of myxamoebae is induced by adverse conditions such as overcrowding, lack of food, accumulation of metabolic products, drought, or overabundance of water (Gray \& Alexopoulos 1968, Haskins et al. 1985). Henney \& Chu (1977a) were able to induce cyst formation in Physarum flavicomum, grown on semi-defined medium, by placing the cells in a non-nutrient salt solution and found that the absence of amino acids was the major factor which caused encystment. On the other hand, excystment occurs by the return of the cysts to an environment supporting growth.

\section{Movement}

Myxamoebae migrate by means of lobose pseudopodial extensions of the cell which are apparently modulated by a contractile actin-myosin system similar to that known in myxomycete plasmodia (Taniguchi et al. 1978, Henney \& Izadpanah 1979). Swarm cells swim with a jerky upand-down motion using their long flagellum. This produces a very limited directional movement and the distance traveled by a swarm cell is normally very short; however, this short distance may, in some situations, be important in improving feeding or mating opportunities. Also, the swimming motion maintains the swarm cell in the water column, and it is thus subject to be carried along with any water movement that may occur.

\section{Cell division}

While the swarm cell stage does not undergo cell division, the myxamoebal stage can divide mitotically to produce a large clonal population of genetically identical cells. The myxamoebal nuclear division involves the centrioles forming the spindle apparatus, breakdown of the nuclear membrane and nucleolus, and movement of the chromosomes to the metaphase plate, followed by separation of the two sets of chromosomes to the poles during anaphase, and the reformation of the nuclear membrane around the two new nuclei (Kerr 1967, Aldrich 1969, Hinchee \& Haskins 1980a). Cytokinesis involves the pinching in of the cell membrane between the two nuclei and the separation of the dividing cell into two new cells. Mitotic division in the plasmodial stage differs in that the centrioles are not present or involved in producing the spindle apparatus and the nuclear 
membrane does not break down during division (Kerr 1967, Aldrich 1969, Hinchee \& Haskins 1980b).

\section{Nutrition}

Both myxamoebae and swarm cells ingest bacteria, yeasts and other small organic particles by surrounding and engulfing them into a membrane bound vacuole, and then digesting them in food vacuoles (Lister 1890, Gilbert 1928b). While no one has systematically researched the food preferences of amoeboflagellates, researchers have generally found that some bacterial species, such as Escherichia coli and Klebsiella pneumoniae are easily digested and others such as Bacillus subtilis are not (Kerr \& Sussman 1958, Haskins 1968). A study by one of the authors (Clark unpublished) found that a number of bacterial species (Bacillus subtilis, B. cerus, B. lentus, Achromobacter xylosoxidans, Flavobacterium species group IIB) accumulated in amoeboflagellate cultures since they were very resistant to ingestion or digestion by the amoeboflagellates. Hoppe \& Kutschera (2015) have shown that the myxamoebae of Lycogala epidendrum, Tubulifera arachoidea and Trichia decipiens display considerable differences in cell motility towards three different species of bacteria, which may indicate differences in food preferences. The amoeboflagellates of most species are cultured on agar using a microorganism (bacteria or yeast) derived from the original isolation culture (see Haskins \& Wrigley de Basanta 2008). The finding that the amoeboflagellates of the nivicolous species Lepidoderma chailletii and Physarum nivale grow best at $2^{\circ}$ may be due to a preference for a cold adapted microorganism (Shchepin et al. 2014). Axenic growth of myxamoebae using heat or formalin killed bacteria has been accomplished with isolates of Badhamia curtissi (Ross 1964), Didymium iridis including D. nigripes (Kerr 1963, Schuster 1964a, Silliker \& Collins 1988), Physarum cinereum (Schuster 1964b), P. rigidum (Henney \& Henney 1968), and Stemonitis flavogenitia Hu \& Clark 1986). However, only Didymium iridis (Balamuth \& Gong 1975), Physarum flavicomum (Henney \& Asgari 1975), P. polycephalum (Goodman 1972, McCullough \& Dee 1976), Echinostelium minutum (Haskins 1970), and Stemonitis flavogenita (Clark et al. 1990) have been grown on defined or semi-defined medium. Interestingly, except for a number of vitamins and hematin, most of these defined media are generally rather simple and consist of minerals, amino acids and a carbohydrate such as glucose (Clark et al. 1990).

\section{Culture}

Isolated single spores will germinate to produce myxamoebae, and these myxamoebae, or isolated single myxamoebae, when placed on a weak nutrient agar plate with a bacterial food source will grow into a large clonal population of genetically identical cells which can be used to study myxomycete genetics and biology (see Haskins \& Wrigley de Basanta 2008, Clark \& Haskins 2011). These clones can be maintained by periodical transfers of a loopful of amoebal and bacteria suspension from the old plate to a new plate with the addition of sterile water to spread the culture. Since these clones are potentially immortal (Clark 1992) and form resistant cysts, they can be maintained for long term on agar slants in screw cap test tubes, or they can be lyophilized using a vacuum system (Kerr 1965b, Davis 1965).

\section{Plasmodial formation}

Plasmodia are produced by the amoeboflagellate stage via the formation of a diploid zygotic cell by means of sexual fusion (heterothallic system), or by the conversion of an apogamic diploid amoeboflagellate into a plasmodium (non-heterothallic system) see reviews by Clark \& Haskins (2010, 2013). In the sexual cycle amoeboflagellates differing at a multiple allelic mating system (Collins 1963) undergo syngamy (Bailey et al. 1990) after they have become competent upon reaching a critical cell density (Shipley \& Holt 1982); while in the apogamic cycle, the amoeboflagellates are diploid, due to automixis (see Clark \& Haskins 2013), and convert to plasmodia when they become competent. The zygotic or diploid amoeboflagellate cell apparently undergo a number of biochemical changes in their cell membrane (Ross \& Shipley 1973) and a 
series of mitotic nuclear divisions without cell division to produce the multinucleate plasmodium. In some clonal amoeboflagellate haploid populations of heterothallic isolates, haploid plasmodia may be formed without crossing (Collins \& Ling 1968, Yemma \& Therrien 1972, Anderson \& Truit 1981); however, the cause of this formation is unknown and the frequency of production and vigor of the plasmodium can vary greatly between different clonal populations.

\section{Discussion}

In the standard heterothallic myxomycete life cycle the diploid plasmodial trophic stage alternates with the haploid amoeboflagellate trophic stage, with the plasmodium converting to the amoeboflagellate stage by means of sporulation and meiosis in the spores, and the amoeboflagellates converting to plasmodia by syngamy of competent amoeboflagellates after they reach a critical density. In the apomictic strains, the morphology remains the same but spore meiosis is replaced by automixis and the resulting diploid amoeboflagellates can convert directly into plasmodia without syngamy when they become competent.

The small spores, which are produced in large number, are readily dispersed by wind currents and they are also a highly resistant stage that can last several years without germinating when conditions are unfavorable. Amoeboflagellates can also form resistant cysts and they are potentially immortal, and they can thus maintain reservoir populations under marginal conditions where conversion to plasmodia and sporulation is unlikely. Therefore, the spores and amoeboflagellates apparently serve (along with plasmodial sclerotia) as widespread reservoirs that can rapidly develop into plasmodia and sporophores when local micro-environments become favorable. This ability to survive as reservoirs under unfavorable conditions can help explain the occurrence of substantial amoeboflagellate populations in many soils and other environments (Feest \& Madelin 1985, Stephenson et al. 2011); and the ability of some species to survive and complete their life cycle under harsh conditions such as mountain snow bank edges (Ronikier et al. 2010) and arid deserts (Wrigley de Basanta et al. 2009).

The recent use of environmental RNA analysis (Komono et al. 2012) in place of DNA universal primers, which greatly underestimates the myxomycetes, has shown that a very diverse assemblage of species sequences can be found in many environments and that myxomycetes may comprise up to fifty percent of the significant amoebozoan population in some situations (Stephenson et al. 2011). Since some environments, from which amoeboflagellates have been isolated, would appear to be unable to support the complete myxomycete life cycle which includes plasmodia and sporulation; it is quite likely that divergent clonal amoeboflagellate populations have arisen which can no longer sporulate, and thus they are effectively soil amoebae. This of course could produce major taxonomic problems since it would be difficult to identity and correctly name them. Unfortunately this process has already occurred with a number of myxomycete amoeboflagellates isolated by protozoologists for whom the complete life cycle (if present) was unknown; these isolates were thereby described as Hperamoeba spp. Since DNA sequences indicated that these isolates belonged to a number of myxomycete genera, they were later transferred to those genera (for example Hperamoeba dachnaya became Didymium dachnaya) based on the DNA sequence analysis (Fiore-Donno et al. 2010). If these amoeboflagellate isolates are truly orphan life cycle stages, there may be a legal (if unnecessary) justification for the new names; however, it would have been more appropriate to propose these names after it had been shown that the DNA sequences did not match the DNA sequences of any validly named species in that genus, which did not occur since DNA sequences are known for only a relatively small percentage of the known validly described Didymium species. On a final note, a series of microscopic movies by Haskins, some of which include the amoeboflagellate stages, is now available on-line; go to TIB: AV-Portal, open the portal and then search for Haskins to find the film file. 


\section{Acknowledgements}

This review is an attempt to distill the work and ideas of a great many researchers. However, such an attempt can never do justice to everyone's contribution, and we can only say that we tried to do our best, and hope that we have not committed too many major omissions

\section{References}

Abe S. 1941 - Über die physiologischen Untersuchungen der Sporenkeimung bei Myxomyceten II. Der Einfluss des pH-Wertes der Lösungen auf die Sporenkeimung. Botanical Magazine (Tokyo) 55, 139-149.

Aldrich HC, Blackwell M. 1976 - Resistant structures in the myxomycetes. In (eds. Weber D, Hess W.) The fungal spore, form and function. John Wiley and Sons, New York.

Aldrich HC. 1967 - The ultrastructure of meiosis in three species of Physarum. Mycologia 59, $127-148$.

Aldrich HC. 1968 - The development of flagella in swarm cells of the myxomycete Physarum flavicomum. Journal of General Microbiology 50, 217-22.

Aldrich HC. 1969 - The ultrastructure of mitosis in myxamoebae and plasmodia of Physarum flavicomum. American Journal of Botany 56, 290-299.

Alexopoulos CJ. 1960 - Morphology and laboratory cultivation of Echinostelium minutum deBary. American Journal of Botany 47, 37-43.

Anderson RW, Truit CI. 1983 - A new type of plasmodial formation in Physarum polycephalum. Genetic Research 42, 285-296.

Bailey J, Anderson RW, Dee J. 1990 - Cellular events during sexual development from amoeba to plasmodium in the slime mold Physarum polycephalum. Journal of General Microbiology 136, 739-751.

Balamuth W, Gong T. 1975 - Growth of the slime mold Didymium iridis in axenic culture. Journal of Protozoology 22, 12A.

Bechtel DB. 1977 - Spore wall formation in the myxomycete Physarella oblonga. American Journal of Botany 64, 111-116.

Blackwell M, Laman TG, Gilbertson RL. 1982 - Spore dispersal in Fuligo septica (Myxomycetes) by Lathridiid beetles. Mycotaxon 14, 58-60.

Boic D. 1925 - Über den chemischen Character der Peridie, des Kapillitiums und der Sporenmembranen bei Myxomyzeten. Acta Botanica Institut Botanischen Universitat Zagreb 1, 44-63.

Braun KL. 1971 - Effect of aeration on the germination of Fuligo septica spores. Mycologia 63, 669-671.

Brodie HJ, Gregory PH. 1953 - The action of wind in the dispersal of spores from cup-shaped plant structures. Canadian Journal of Botany 31, 402-410.

Brown RM, Larson DA, Bold HC. 1964 - Airborne algae: their abundance and heterogeneity. Science 143, 583-585.

Cadman EJ. 1931 - Life history and cytology of Didymium nigripes. Transactions of the Biological Society of Edinburgh 57, 93-143.

Clark J. 1992 - The myxamoebae of Didymium iridis and Physarum polycephalum are immortal. Mycologia 84, 116-118.

Clark J. 2003 - Biosystematics of the myxomycete Arcyria cinerea. Mycotaxon 83, 343-346.

Clark J, Brown D, Hu F-S. 1990 - Growth of the myxomycete Stemonitis flavogenita on a defined minimal medium. Mycologia 82, 385-386.

Clark J, Haskins EF. 2010 - Reproductive systems in the myxomycetes: a review. Mycosphere 1, 337-367.

Clark J, Haskins EF. 2011 - Principles and protocols for genetical study of myxomycete reproductive systems and plasmodial coalescence. Mycosphere 2, 487-496. 
Clark J, Haskins EF. 2013 - The nuclear reproductive cycle in the myxomycetes: a review. Mycosphere 4, 233-248.

Collins OR, Gong T, Clark J, Tang HC. 1983 - Apomixes and heterothallism in Stemonitis flavogenita (Myxomycetes, Stemonitales). Mycologia 75, 683-672.

Collins OR, Ling H. 1968 - Clonally produced plasmodia in heterothallic isolates of Didymium iridis. Mycologia 60, 858-868.

Collins OR. 1963 - Multiple alleles at the incompatibility locus in the myxomycete Didymium iridis. American Journal of Botany 50, 477-480.

Cooke WRI, Holt EM. 1928 - Some observations on the germination of spores of some species of Mycetozoa. Mycologia 20, 340-352.

Dahlberg KR, Franke RG. 1977 - Spore germination in the myxomycete Fuligo septica: evidence for the existence of a soluble autocatalytic factor. Mycologia 69, 96-108.

Davis EE. 1965 - Preservation of myxomycetes. Mycologia 57, 986-988.

deBary A. 1864 - Die Mycetozoen (Schleimpilze). Ein Beitrag zur Kenntnis der Niedersten Thiere. Zeitschrift fûr Wissenschaftliche Zoologie 10, 88-175.

Demaree RS, Kowalski DT. 1975 - Fine structure of five species of myxomycetes with clustered spores. Journal of Protozoology 22, 85-88.

Dixon PA. 1963 - Spore liberation by water drops in some myxomycetes. Transactions of the British Mycological Society 46, 615-619.

Dykstra MJ, Aldrich HC. 1978 - Successful demonstration of an elusive cell coat in amoebae. Journal of Protozoology 25, 38-41.

ElHage N, Little C, Clark J, Stephenson S. 2000 - Biosystematics of the Didymium squamulosum complex. Mycologia 92, 54-64.

Elliott EW. 1949 - The swarm-cells of myxomycetes. Mycologia 41, 141-170.

Erbisch FH. 1964 - Myxomycete spore longevity. The Michigan Botanist 3, 120-121.

Feest A, Madelin MF. 1985 - Numerical abundance of myxomycetes (myxogastrids) in soils in the west of England. FEMS Microbiology Ecology 31, 353-360.

Fiore-Donno AM, Nikolaev SI, Nelson M, Pawlowski J, Cavalier-Smith T, Baldauf SL. 2009 Deep phylogeny and evolution of slime moulds (Mycetozoa). Protist 161, 55-70.

Fiore-Donno AM, Novozkilov YK, Meyer M, Schnittler M. 2011 - Genetic structure of two Protist species (Myxogastria, Amoebozoa) suggests asexual reproduction in sexual amoebae. PLoS ONE 6, e22872.

Gaither TW, Collins OR. 1984 - Comparative SEM observations of sporophore characteristics in three species of Didymium (Myxomycetes, Physarales). Mycologia 650-664.

Gilbert FA. 1928a - A study of the method of spore germination in myxomycetes. American Journal of Botany 15, 345-352.

Gilbert FA. 1928b - Observations on the feeding habits of the swarm cells in certain myxomycetes. American Journal of Botany 15, 473-484.

Gilbert FA. 1929 - Factors influencing the germination of myxomycete spores. American Journal of Botany 16, 280-286.

Goodman EM. 1972 - Axenic culture of myxamoebae of the myxomycete Physarum polycephalum. Journal of Bacteriology 111, 242-247.

Gray WD, Alexopoulos CJ. 1968 - Biology of the Myxomycetes. Ronald Press, New York.

Haskins EF, Hinchee AA, McGuinness M. 1985 - The amoebal and protoplasmodial cyst phase of Echinostelium minutum. Mycologia 77, 253-258.

Haskins EF, Hinchee AA. 1992 - Spore germination in Echinostelium minutum. Mycologia 84, 916-920.

Haskins EF, McGuinness M, Berry CS. 1983 - Semimorula: new genus with myxomycete and protostelid affinities. Mycologia 75, 153-158.

Haskins EF, McGuinness M. 1986 - Comparative ultrastructural observations of spore wall structure in six species of Echinostelium and three species of Eumycetozoa. Mycologia 78, 613-618. 
Haskins EF, Therrien CD. 1978 - The nuclear cycle in the myxomycete Echinostelium minutum. 1. Cytophotometric analysis of nuclear DNA of the amoebal and plasmodial phases. Experimental Mycology 2, 32-40.

Haskins EF, Wrigley de Basanta D. 2008 - Methods of agar culture of myxomycetes: an overview. Revista Mexicana de Micologia 27, 1-7.

Haskins EF. 1968 - Developmental studies on the true slime mold Echinostelium minutum. Canadian Journal of Botany 44, 1309-1315.

Haskins EF. 1970 - Axenic culture of the myxamoebae of Echinostelium minutum. Canadian Journal of Botany 48,663-664.

Haskins EF. 1976 -High voltage electron microscopical analysis of chromosomal number in the slime mold Echinostelium minutum de Bary. Chromosoma 56, 95-100.

Haskins EF. 1978 - A study of the amoebae-flagellate transformation in the slime mold Echinostelium minutum de Bary. Protoplasma 94, 193-206.

Henney HR, \& Henney M. 1968 - Nutritional requirements for the growth in pure culture of the myxomycete Physarum rigidum and related species. Journal of General Microbiology 53, 333-339.

Henney HR, Asgari M. 1975 - Growth of the haploid phase of the myxomycete Physarum flavicomum in defined minimal medium. Archive of Microbiology 102, 175-178.

Henney HR, Chu P. 1977a - Differentiation of Physarum flavicomum: Metabolic patterns and the role of amino acids in the control of encystment. Experimental Mycology 1, 41-51.

Henney HR, Chu P. 1977b - Chemical analysis of cell walls from macrocysts and micro- sclerotia of Physarum flavicomum: comparison to slime coat from microplasmodia. Experimental Mycology 1, 83-91.

Henney HR, Izadpanah M. 1979 - Purification of actin and a 51,000-dalton protein from haploid cells of Physarum flavicomum. Experimental Mycology 3, 310-320.

Hinchee AA, Haskins EF. 1980a - Open spindle nuclear division in an amoebal phase of the acellular slime mold Echinostelium minutum with chromosomal movements related to pronounced rearrangement of spindle microtubules. Protoplasma 102, 117-130.

Hinchee AA, Haskins EF. 1980b - Closed spindle nuclear division in the plasmodial phase of the acellular slime mold Echinostelium minutum. Protoplasma 102, 235-252

Hoppe T, Kutschera U. 2015 - Species-specific cell mobility of bacterial-feeding myxamoebae in plasmodial slime molds. Plant Signaling \& Behavior DOI: 10.1080/15592324.2015.1074368.

Hoppe T, Schwippert WW. 2014 - Hydrophobicity of myxomycete spores: An undescribed aspect of spore ornamentation. Mycosphere 6, 601-606.

Howard FL. 1931 - The life history of Physarum polycephalum. American Journal of Botany 18, 116-133.

Hu F-S, Clark J. 1986 - Axenic culture of the myxomycete Stemonitis flavogenita. Mycologia 78, 478-482.

Iwata D, Isibashi M, Yamamoto Y. 2003 - Cribrarione B, a new naphthoquinone pigment from the myxomycete Cribraria cancellata. Journal of Natural Products 66, 1611-1612.

Jahn E. 1905 - Myxomyetenstudien. 4. Die Keimung der Sporen. Berichte der Deutchen Botanischen Gesellschaft 23, 489-497.

Kamono A, Kojima H, Matsumoto J, Kimitake K, Fukai M. 2009 - Airborne myxomycete spores: detection using molecular techniques, Naturwissenschaften 96, 147-151.

Kamono A, Meyer M, Cavalier-Smith T, Fukui M, Fiore-Donno AM. 2012 - Exploring slime mould diversity in high-altitude forests and grasslands by environmental RNA analysis. Federation of European Microbiological Societies: Microbiological Ecology 11, 1-12.

Keller HW, Snell HL. 2002 - Feeding activities of slugs on myxomycetes and macrofungi. Mycologia 94, 757-760.

Kerr NS, Sussman M. 1958 - Clonal development of the true slime mold, Didymium nigripes. Journal of General Microbiology 19, 173-177. 
Kerr NS. 1960 - Flagellar formation by myxamoebae of the true slime mold Didymium nigripes. Journal of Protozoology 7, 103-108.

Kerr NS. 1963 - The growth of the myxamoebae of the true slime mold, Didymium nigripes in axenic culture. Journal of General Microbiology 32, 409-416.

Kerr NS. 1965a - Inhibition by streptomycin of flagellar formation in a true slime mold. Journal of Protozoology 12, 276-278.

Kerr NS. 1965b - A simple method of lyophilization for the long-term storage of slime molds and small soil amoebae. BioScience 15, 469.

Kerr NS. 1982 - Spore germination in the true slime mold Didymium nigripes. Journal of Protozoology 29, 242-246.

Kerr SJ.. 1967 - A comparative study of mitosis in amoebae and plasmodia of the true slime mold Didymium nigripes. Journal of Protozoology 14, 439-445.

Koevenig JL. 1961 - Slime molds I: Life cycle. Bureau audio visual instruction film U5518, University of Iowa, Iowa City.

Koevenig JL. 1964 - Studies on life cycle of Physarum gyrosum and other myxomycetes. Mycologia 56, 170-164.

Laane MM, Haugli FB. 1976 - Nuclear behavior during meiosis in the myxomycete Physarum polycephalum. Norwegian Journal of botany 23, 7-21.

Lister A. 1890 - Notes on the ingestion of food materials by the swarm cells of Mycetozoa. Journal of the Linnean Society (Botany) 25, 435-441.

Lister A. 1901 - On the cultivation of Mycetozoa from spores. Journal of Botany 39, 5-8.

Lizárraga M, Illana C, Moreno G. 1999 - SEM studies of the myxomycetes from the peninsula of Baja California (Mexico), II. Hemitrichia to Trichia. Annales Botanici Fennici 36, 187210.

Loganathan P, Paramasivan P, Kalyanasundaram I. 1989 - Melanin as the spore wall pigment of some myxomycetes. Mycological Research 92, 286-292.

Martin CW, Alexopoulos CJ. 1969 - The Myxomycetes. The University of Iowa, Iowa City.

McCormick JJ, Blomquist J, Rusch HP. 1970 - Isolation and characterization of a galactosamine wall from spores and spherules of Physarum polycephalum. Journal of Bacteriology 194, $1119-1125$.

McCullough C, Dee J. 1976 - Defined and semi-defined media for the growth of amoebae of Physarum polycephalum. Journal of General Microbiology 95, 151-158.

McManus MA. 1958 - In vivo studies of plasmogamy in Ceratiomyxa. Bulletin of the Torrey Botanical club 85, 28-37.

Mims CW, Rogers MK. 1973 - An ultrastructural study of spore germination in the myxomycete Stemonitis virginiensis. Protoplasma 78, 243-254.

Mims CW. 1971 - An ultrastructural study of spore germination in the myxomycete Arcyria cinerea. Mycologia 63, 586-601.

Mims CW. 1972 - Spore-wall formation in the myxomycete Arcyria cinerea. Transactions of the British Mycological Society 59, 477-481.

Murray PM, Feest A, Madelin MF. 1985 - The number of viable spores in the alimentary tracts of earthworms and in earthworm casts. Botanical Journal of the Linnean Society 91, 359-366.

Neubert H, Baumann K. 1987 - Myxomyceten aus der Bundesrepublik Deutschland IV. Schlûssel $\mathrm{zu}$ den Ordnungen und $\mathrm{zu}$ den Familien, Gattungen und Arten der Ordung Trichiales. Carolinea 45, 51-76.

Neubert H, Notwotny W, Baumann K. 1989 - Myxomyceten aus der Bundesrepublik Deutschland V. (Mit Berûcksichtigung von Vorkommen in Oberösterreich). Carolinea 47, 25-46.

Newton AF, Stephenson SL. 1990 - A beetle slime mold assemblage from northern India (Coleoptera, Myxomycetes). Oriental Insects 24, 197-218.

Olive LS. 1960 - Echinostelium minutum. Mycologia 52, 159-161. 
Rammeloo J. 1974 - Structure of the epispore of the Trichiaceae (Trichiales, Myxomycetes), as seen with the scanning electron microscope. Bulletin de la Societe Royale de Botanique de Belgique 107, 353-395.

Rammeloo J. 1975 - Structure of the epispore of the Stemonitales (Myxomycetes), as seen with the scanning electron microscope. Bulletin del Jardin Botanique National de Belgique 45, 301306.

Randall LP, Lynch DL. 1974 - Spore ultrastructure of the myxomycete Physarum polycephalum. Journal of Botany 61, 513-524.

Rebhahn M, Schnittler M, Liebermann B. 1999 - Taxonomic relevance of pigment patterns in Arcyria species (Trichiales, Myxomycetes) including Arcyodes incarnata. Nova Hedwigia 69, 425-427.

Ronikier A, Lado C, Meyer M, Wrigley de Basanta D. 2010 - Two new species of nivicolous Lamproderma (Myxomycetes) from the mountains of Europe and America. Mycologia $102,718-728$.

Ross IK, Shipley GL. 1973 - Sexual and somatic fusion in the heterothallic slime mold Didymium iridis 2. Effects of actinomycin D, cyclohexamide and lysosome stabilizers. Microbios 7, $165-171$.

Ross IK. 1957 - Syngamy and plasmodial formation in the Myxomycetes. Journal of Botany 44, 843-850.

Ross IK. 1964 - Pure cultures of some myxomycetes. Bulletin of the Torrey Botanical Club 91, 23-31.

Scheetz RW, Alexopoulos CJ. 1971 - The spores of Badhamia gracilis (Myxomycetes). Transactions of the American Microscopical Society 90, 473-475.

Scheetz RW, Alexopoulos CJ. 1976 - Studies on the spores of myxomycetes. II. Physarum straminipes. Mycotaxon 4, 335-339.

Schnittler M, Mitchell DW. 2000 - Species diversity in myxomycetes based on the morphological species concept - a critical examination. Stapfia 73, 55-62.

Schnittler M, Tesmer J. 2008 - A habitat colonization model for spore dispersal organisms - does it work with Eumycetozoans? Mycological Research 112: 697-707.

Schnittler M, Unterseher M, Tesmer J. 2006 - Spore richness and ecological characterization of myxomycete and myxomycete-like organisms in the canopy of a temperate deciduous forest. Mycologia 98, 223-232.

Schoknecht JD, Small EB. 1972 - Scanning electron microscopy of the acellular slime molds (Mycetozoa $=$ Myxomycetes $)$ and the taxonomic significance of surface morphology of spores and accessory structures. Transactions of the American Microscopical Society 91,380-410.

Schuster F. 1964a - Electron microscope observations on spore formation in the true slime mold Didymium nigripes. Journal of Protozoology 11, 207-216.

Schuster F. 1964b - Ultrastructure and growth studies on slime molds. Argonne National Laboratory ANL-6771, 90-74.

Schuster F. 1965 - Ultrastructure and morphogenesis of solitary stages of true slime molds. Protistologica 1, 49-62.

Shchepin O, Novozhilov Y, Schnittler M. 2014 - Nivicolous myxomycetes in agar culture: some results and open problems. Protistology 8, 53-61.

Shipley GL, Holt CE. 1982 - Cell fusion competence and its induction in Physarum polycephalum and Didymium iridis. Developmental Biology 90, 110-117.

Silliker ME, Collins OR. 1988 - Non-mendelian inheritance of mitochondrial DNA and ribosomal DNA in a myxomycete, Didymium iridis. Molecular and General Genetics 213, 370-378.

Smart RF. 1937 - Influence of certain external factors on spore germination in the myxomycetes. American Journal of Botany 24, 145-159.

Smith EC. 1929 - Some phases of spore germination in myxomycetes. American Journal of Botany $16,645-650$. 
Solis BC. 1962 - Studies on the morphology of Physarum nicaraguense Macbr. Master's Thesis, University of Iowa, Iowa City.

Stephenson SL, Fiore-Donno AM, Schnittler M. 2011 - Myxomycetes in soil. Soil Biology and Biochemistry 43, 2237-2242.

Stephenson SL, Stempen H. 1994 - Myxomycetes. A handbook of slime molds. Timber Press, Portland, Oregon.

Taniguchi M, Yamazaki K, Ohta J. 1978 - Extraction of contractile protein from myxamoebae of Physarum polycephalum. Cell Structure and Function 3, 181-190.

Tesmer J, Schnittler M. 2007 - Sedimentation velocity of myxomycete spores. Mycological Progress 6, 229-234.

Therrien CD, Haskins EF. 1981 - The nuclear cycle in the myxomycete Echinostelium minutum. II. Cytophotometric analysis of the nuclear DNA content of the sporangial phase. Experimental Mycology 5, 229-235.

von Stosch, HA. 1935 - Untersuchungen ûber die Entwickungeschichte der Myxomyceteen. Sexualitát und Apogamie bei Didymiancen. Planta 23, 623-656.

Winsett K, Stephenson SL. 2008 - Using ITS sequences to assess intraspecific genetic relationships among geographically separate collections of the myxomycete Didymium squamulosum. Revista Mexicana de Micologia 27, 59-63.

Winsett K, Stephenson SL. 2011 - Global distribution and molecular diversity of Didymium difforme. Mycosphere 2, 135-146.

Winsett K. 2011 - Intraspecific variations in response to spore-to-spore cultivation in the myxomycete Didymium squamulosum. Mycosphere 2, 555-564.

Wright M, Moissand A, Mir L. 1979 - The structure of flagellar apparatus of the swarm cell of Physarum polycephalum. Protoplasma 100, 231-136.

Wrigley de Basanta D, Lado C, Estrada-Torres, Stephenson SL. 2009 - Description and life cycle of a new Didymium (Myxomycetes) from arid regions of Argentina and Chile. Mycologia $101,707-715$.

Yemma JJ, Therrien CD. 1972 - Quantitative micro-spectrophotometry of nuclear DNA in selfing strains of the myxomycete Didymium iridis. American Journal of Botany 59, 823-835. 